\title{
THE DETERMINANTS OF THE COMPETITIVENESS OF LITHUANIAN EXPORT: MACROECONOMIC APPROACH
}

\author{
Rita REMEIKIENE $\dot{1}^{1}$, Ligita GASPARĖNIENE $\dot{E}^{2}$, Alius SADECKAS ${ }^{3}$ \\ ${ }^{1,2}$ Lithuanian Institute of Agrarian Economics \\ ${ }^{3}$ Mykolas Romeris University, Vilnius, Lithuania \\ E-mails: rita.remeikiene35@gmail.com ${ }^{1}$ (corresponding author); \\ ligita.gaspareniene@laei.lt ${ }^{2}$; alius@ebiuras.lt ${ }^{3}$
}

Received 06 November 2018; accepted 26 November 2018

\begin{abstract}
The development of an appropriate export promotion strategy in any country calls for consideration of such countrylevel determinants as macroeconomic indicators and cultural elements. Small economies, like Lithuania, must have a clear understanding of which macroeconomic factors most significantly contribute to the competitiveness of their exports. This article is aimed at assessment of the competitiveness of Lithuanian export in the macroeconomic context.

The main purpose of the research is to assess the determinants of the competitiveness of Lithuanian export in the macroeconomic context. For accomplishment of the defined purpose, the following objectives were raised: 1 ) to review the general determinants of export competitiveness; 2) to develop the methodology for assessment of the country's export competitiveness in the macroeconomic context; 3 ) to empirically assess the impact of macroeconomic determinants on the competitiveness of Lithuanian export over the period 2007-2015. The research methods include comparative and systematic literature analysis, correlation and regression analysis.

It has been found that GDP (gross domestic product) per capita and general state's revenue from taxes and social contributions explain the trends of Lithuanian export by 99.1 percent. A very strong correlation has been estimated between Lithuanian export and terms of financing for exporting enterprises, a negative medium-strong correlation has been estimated between the country's export and its general tax level, while a positive medium-strong correlation has been captured between the country's export and its minimum wages.

Novelty. The results lead to the conclusion that the competitiveness of Lithuanian export is mainly affected by the state's tax policy, terms of financing for exporting enterprises and social wage strategies. By improving the above-mentioned areas, the country could occupy stronger competitive positions in international markets.
\end{abstract}

Keywords: export, factors, Lithuania, competition, macroeconomic environment, determinants.

JEL Classification: B17, F18.

\section{Introduction}

Topic relevance. International competitiveness is an important area of economics and management. Although the term "competitiveness" is widely-spread, its meaning still remains obscure, in particular, as far as it is concerned with an industrial or a country-level investigation (Pascucci 2018). Scientific literature is rich in different definitions of "competitiveness" which can be analysed at three basic levels: a firm level (or a microeconomic level), an industrial level (or a mesoeconomic level) and a country level (or a macroeconomic level). Depending on a particular level, the conceptualization and measuring of competitiveness may significantly vary. Although scientists separate different levels of competitiveness, these three levels are closely interrelated: a country-level competitiveness is characterized by the economic efficiency of different industries, while industrial competitiveness is affected by the efficiency of the firms operating in a particular industry. In this article, we lean on Tyson's (1992) definition whereby competitiveness of a country is defined as its ability to produce goods or services

Copyright (C) 2019 The Authors. Published by VGTU Press.

This is an Open Access article distributed under the terms of the Creative Commons Attribution License (http://creativecommons.org/licenses/by/4.0/), which permits unrestricted use, distribution, and reproduction in any medium, provided the original author and source are credited.. 
that fulfil the requirement of international competition while maintaining a rising living standard. In other words, international competitiveness of a country represents its ability to maintain strong positions in international trade with respect to other countries worldwide. International competitiveness of a country is usually driven by low labour costs or high productivity. Hence, competitiveness of a country can be explained as upkeeping of high growth rates compared to those demonstrated by trade partners (Huo 2014).

As this article addresses the issues of macroeconomic competitiveness of the certain country, it should be noted that macroeconomic competitiveness is related to such macroeconomic indicators as GDP growth, standards of living, income distribution and employment (Masmoudi and Charfi 2013). The concept of international competitiveness is often used for the analysis of macroeconomic performance in different countries. It compares, for a country and its trading partners, a number of salient economic features that can help explain international trade trends (Durand and Giorno 1987). In most general sense, it is stated that export represents one of the main forms of corporate involvement in international trade. According to Morgan (1997), the majority of governments in new industrial and developing economies treat export as a strategy that allows local business companies to gain a competitive advantage. For that purpose, different export promotion programs are employed. Since export competitiveness in an industrial sector represents a function of the capacity to sell an internationally-demanded product at the quantity, quality, price and time required, it can also be treated as a function of many variables in the context of advanced technologies, better quality and improved marketing techniques (Muratoğlu and Muratoğlu 2016).

One of the ways to increase the volumes of export on a national level is to encourage business companies to export as much as possible. Thus, the research in exporters' behaviour and the problems of export management is topical for both public and private sectors as it is linked to the success of future exports (Katsikeas et al. 1996). In this article, we research the factors of the macroeconomic environment so as to assess the potential of Lithuanian export competitiveness. According to Bruneckienè and Paltanavičienè (2012), scientific analysis in the area of export competitiveness is burdened by the lack of an unanimous scientific attitude towards the concept of competiveness, absence of a clear academic opinion on a country's international competitiveness (it is often unified with the concept of export), the abundance of export determinants and the complexity of the impact of these determinants on the development of national exports.

Thus far, scientific studies have focused on the following determinants of export competitiveness: Àlvarez et al.
(2013) researched the impact of previous export experience on new export markets; Deng and Hou (2014) analysed the effects of financial development (i.e. size, lending efficiency, term structure of bank loans and degree of state intervention in financial resource allocation) on the survival of exports; Lederman et al. (2016) studied the impact of export promotion on services and subsidies, etc.. Nevertheless, scientific literature is still not rich in comprehensive studies addressing the determinants of export competitiveness on a national level in the macroeconomic context. This gap in the scientific literature allows to formulate the following scientific problem: what determinants of export competitiveness are important in the macroeconomic context with consideration of a country's specificity?

Research object: the determinants of export competitiveness.

Research aim: to assess the determinants of the competitiveness of Lithuanian export in the macroeconomic context.

In order to achieve the main aim of the research, the following objectives were set:

1) to review the general determinants of export competitiveness;

2) to develop the methodology for assessment of the determinants of export competitiveness in the macroeconomic context;

3) to empirically assess the impact of macroeconomic determinants on the competiveness of Lithuanian export over the period 2007 to 2015.

Research methods: comparative and systematic literature analysis, correlation and regression analysis.

\section{The general determinants of export competitiveness}

The development of export plays an important role in economic growth of a country. Hence, the analysis of export competitiveness should be based on assessment of the economic indicators and market conditions that have the most significant impact on the growth of a national economy. Fetscherin et al. (2010) treats export competitiveness as a degree of participation in international trade. According to Ricardo (1951), different countries have their comparative advantages, so the countries opened to international trade can gain from their comparative advantage. Ricardo's (1951) model proposes that international trade can help countries expand their markets through the economy of scale. Feestra (2003) analysed Heckscher and Ohlin's (1991) model in which the exports of different countries are affected by different determinants. The main groups of the determinants of export competitiveness are presented below.

Langviniene et al. (2010) argue that a demographic situation is related to human resources. The main problems 
arising in this area and disrupting business activities are associated with migration of people, labour force structure and employment policies. Langvinienè et al. (2010) emphasize that human resources are vital as no form of business is possible without them. A favourable demographic situation in a country not only provides a skilled labour force, but also increases a potential of consumers. Thus, a demographic advantage of a given country is one of the key factors to encourage entrepreneurs to invest and make long-term profits.

There exists a direct relationship between export performance and the human factor, and this relationship is widely researched in economic literature. Investment in human capital (i.e. higher education and its integration into labour force) appears to be an important factor contributing to export performance. Recently more and more focus has been placed on the role of intellectual capital. Intellectual capital has become not only a human factor associated with knowledge, but also an active value contributing to the value-added of a product (Pucar 2012).

In the context of globalization, culture is acquiring a global nature, so for stimulation of an efficient business strategy, it is extremely important to assess the origins of traditions, cultures and behaviours. In order to develop exports, it is a must to understand the ethical standards and social responsibility concepts applied in different countries.

The significance of culture in entrepreneurial decision making can be described by three main elements (Langvinienè et al. 2010):

- Business environment. It refers to the role of business managers in business fairs and exhibitions, building of working conditions, employee participation in the process of decision making, and the level of interrelationships.

- Marketing. It means that all the decisions related to the marketing of goods or services (advertising, elegance, urbanization and quality levels) must respond to the needs of target customers.

- Social attitude. It refers to the approach to work, resources, politics, religions, respect to laws and social institutions, social classes and morality.

Exporters primarily seek the expansion to culturally close markets since business negotiations are more successful when negotiating parties share a similar cultural medium. According to Pridotkienè (2011), in order to export a good or service successfully, it is important to understand the internal culture of local companies. Cultural peculiarities of a recipient country are perceived through communication with a buyer's company. Then different approaches to business systems, communication and work culture are revealed.

In technologically developed markets, it is much easier to introduce new products, experiment with substitute goods and quicker respond to any rapid changes in consumer demand. The most important feature of technological business environment is that businesses using new technologies can master the latest equipment and improve their working practices. This allows to reduce prices of goods and services and provides a competitive advantage in the global market (Langvinienè et al. 2010).

Saboniene (2014) argues that export structure depends on the technologies applied in particular industries and a country's industrial development leans on the high-tech structure applied in the manufacturing industry. Transition economies, however, mainly lean on medium and low technologies. The author affirms that the development of the export structure, reduction in the vulnerability of exports and the ability to compete on the basis of lower costs call for innovation, advanced technologies and quality improvements.

Assuming that the intensity of technology determines a country's economic growth and export expansion, it is necessary to analyse the nature of the modern economy based on technological advancement (Umbrasienè 2014).

Melnikas (2014) argues that the high-tech sector is exceptionally significant and requires a special attention, in particular as far as it concerns an economic chain. The development of the high-tech industry plays a major role not only in economy modernization, but also in addressing the most pressing problems of the modern society.

Langvinienè et al. (2010) state that ecological and environmental factors are, beyond any doubt, important for individuals, governments and the public. Sustainable development is a compromise letting match the environmental, economic and social goals, which, in its turn, allows striving for the general welfare for present and future generations within the limits of the environmental impact.

The main areas of environmental protection in the international business-oriented environment are as follows:

- waste management;

- noise reduction;

- reduction of water pollution;

- air pollution control and mitigation of climatic change;

- protection of fauna and flora.

The management of the above-listed areas can comprise adoption of the directives and assignment of the conventions that define the principles necessary to follow, the measures necessary to apply and the minimum requirements necessary to meet.

Environmental protection and ecology are the priority areas under regulation. In order to save healthy business environment, the guidelines for all countries must be clarified, and the appropriate laws to regulate corporate activities must be issued and implemented. Langviniene et al. (2010) note that even though ecological environment at a 
first glance does not appear to have a significant impact on the choice of a business strategy, the factors of the ecological environment are closely linked to the political and legal environment of export.

Langviniene et al. (2010) state that the macroeconomic factors, such as a state's general economic situation and a level of its development, can strongly influence businesses since they affect population's purchasing power, behaviour in the market, product demand and sales.

There are three world-famous economic systems: capitalism, socialism and a mixed system. The authors argue that, in principle, governments of all countries set four main economic goals:

- to employ more people lacking the opportunities to create material wealth, to help them find suitable works that would meet their qualifications and health status, to eliminate gender inequality factors, to develop and apply an adequate legal framework;

- to accelerate the economy; even though economic growth in most industrialized countries is evident, these countries also show the signs of deceleration (e.g., the decline in annual interest rates, the annual decrease in consumer price index observed in the US and the EU, etc.);

- to achieve a low inflation rate;

- to avoid a balance of payments deficit.

The other economic factors that characterize economic environment and are important for business include:

- Market. Establishment of a single market lets small countries develop their economies hand in hand with large economies, ensures free movement of goods, capital and labour among countries, improves business environment and provides an access to the latest technology;

- Foreign and domestic trade. It implies various arrangements for incentives, tariff duties, tax cuts in free trade, anti-dumping policies, countervailing duties and voluntary restrictions;

- Market regulation measures. Taxes, price control, quota;

- Currency policies Introduction of euro in Europe and US dollar in the US and other countries, the use of other currencies, conversion, the forces determining the euro-dollar exchange rate;

- Gross National Product. It changes in accordance with market saturation and destructive impacts of an economic crisis.

Economic development is a fundamental objective of a state's policy. Economics can be defined in two ways: firstly, as a system that can describe the values and capabilities of a society to form, maintain and develop material and immaterial goods and services; secondly, as a prevailing economic system in a defined geographic area which is designed to meet the needs of the society living in this area.
The key priorities affecting the growth and development of an economic structure include (Melnikas 2014):

- an increase in exports providing income growth due to the export expansion to foreign markets; production growth in the domestic territory, i.e. an increase in export provides the preconditions for additional income after sales of domestic products overseas; an increase in manufacturing export within a country; in all cases, a state and a society gain additional economic benefits;

- the improvement of an export structure; it ensures the growth of GDP, national production and national income and creates the preconditions for securing long-term export stability and reliability;

- targeted investment to support exports; it lets achieve economic and other benefits due to foreign investment which has a favourable direct impact on economic growth.

FDI (foreign direct investment), according to Muratoğlu and Muratoğlu (2016), is characterised by complex links with trade and export competitiveness. In most general sense, FDI is often criticised for its negative impact on employment in home countries. Nevertheless, it promotes the growth of export in recipient countries. Literature proposes that FDI may serve as a source of trade origin or a factor that may replace trade. Trade is started when FDI opens an access to a new market and promotes the export from a home country to recipient countries. FDI can also be used for the development of marketing and distribution channels which, in their turn, facilitate the export of final goods and services to recipient countries.

Vijeikis (2012) argues that competition is perceived as an automatic mechanism of a market balance. Competitive economies are capable of creating higher incomes for their population. Global Competitiveness Index covers many different components, each of which reflects a certain part of competitiveness. Saboniene $(2011,2014)$ states that export competitiveness is a topical scientific issue. Export development to a large extent depends on industrial competitiveness which contributes to capital inflows, employment, industrial development and expansion of the production base. Exports enables local industries to achieve economy of scale that would not be possible for a small local market. Export competitiveness is also affected by the attractiveness of and the demand for manufactured goods, as well as by production cost and quality aspects. The intense competition in international markets calls for product/service quality improvement.

According to Kalèdiené and Miliauskas (2011), the concept of competitiveness has many definitions which propose that economic competitiveness is the ability of economics to produce goods and services so as to meet the needs of international markets, at the same time maintaining high and sustainable income. More generally, it may mean the 
ability of regions to generate income while being exposed to external competition. The authors associate export competitiveness with productivity and emphasize that export competitiveness depends on a country, while the role of a government is to shape appropriate conditions and incentives for business. The authors also note that the development of export competitiveness is affected by geographical factors and specialization of industrial sectors.

\section{Research methodology}

Before introducing the methodology of the research, it should be noted that most scientists are inclined to measure national competitiveness by employing three indices: Revealed Comparative Advantage (RCA), Hirschman index (HI) and Constant Market Share Analysis (CMSA). RCA estimates trade performance of an individual country for a particular product (Burange and Karnik 2014, Muratoğlu and Muratoğlu 2016, Romero-Márquez and Moreno-Brid 2015, Pascucci 2018, Bojnec and Fertö 2017, Saboniene 2009, Misztal 2009). Its popularity was determined by the simple interpretation: if the value of RCA is greater than one, it signifies that a country has exported a relatively larger amount of a product than the rest part of the world in the year under consideration. In other words, RCA measures a country's export competitiveness with respect to foreign trade (Burange and Karnik 2014). HI is widely used to measure trade concentration. The index is multiplied by 100 to get rid of fractions, and therefore it ranges between 0 and 100 (lower values indicate a less concentrated trade structure). The competitiveness of Lithuanian export was assessed in the context of the Constant Market Share Analysis (CMSA). The CMSA is a traditional tool to deal with a product-linked and geographical structure of a country's export. The underlying feature of this method is that the countries with strong initial positions in most dynamic markets and products benefit from higher growth of their exports (Kalendienè 2014).

Before developing the methodology for the empirical research, we defined the aim of our empirical study: to assess the impact of economic factors on the volumes of Lithuanian exports over the period 2007-2015. To achieve the defined aim, we employed some mathematical methods (correlation analysis based on Pearson's correlation coefficient and multiple regression analysis) to help us identify the factors that affect the dynamics of Lithuanian export.

In the first stage, in order to identify which economic factors, in numerical terms, have the most significant impact on Lithuanian export, we selected a few quantitative methods, such as correlation and multiple regression analysis. Correlation analysis indicates whether variables are dependent (i.e. whether one variable is decreasing in the dependence on an increase in the other variable, and vice versa), how strong the relationship between the variables is and whether the relationship between the variables is statistically significant (not accidental). In order to ensure reliability of our assessment of the impact of the economic environment on Lithuanian exports, we verified whether there exists any correlation between corruption freedom index, business freedom index, unemployment rate, GDP per capita, foreign direct investment, corruption perception index, general labour force, general state's revenue from taxes and social contributions, inflation, crediting of the private sector, general tax level, minimum wages and volumes of exports in Lithuania over the period 2007-2015.

One of the objectives of the empirical research was to verify the hypothesis of normality factors that were influential to represent economic environment and exports. The condition of normality was considered satisfied if value $p$ was $<0.05$. The description of the factors affecting exports is presented in Table 1.

After estimation of the correlation with SSPS (Statistical Package for the Social Sciences), the program is further subjected to multiple regression, that is applied only to those factors that have value $r$ higher than 0.6 .

\section{Empirical evaluation of the factors influencing Lithuanian export}

Stage 1. Firstly, the hypothesis about normality of all the variable distributions was tested. As a result, p-values (asymp. sig.) were larger than 0.05 , and therefore it was concluded that the distributions were normal and the relations could be researched by using Pearson's correlation coefficient.

The estimation of Pearson's correlation coefficient (indicating which factors had an impact on the level of Lithuanian export over the period 2007-2015) is presented in Table 2. It is considered that $\mathrm{Y}$, as a dependent variable, is an expression of export volumes (in thousand euros), while all other indicators (Xs) are independent variables.

Stage 2. Herein the variables named in Stage 1 will be included into the multiple regression model (X3, X7, X9, $\mathrm{X} 10$ and X11) The multiple regression model is statistically significant since $p$ is less than $0.05(p=0.000)$, and the value of the determination coefficient $(\mathrm{R})$ is high and equal to 0.99 . This means that the independent variables in the model by 99 percent explain the changes in Lithuanian export over the period under consideration.

In order to estimate the statistical significance of each variable in the model, values $\mathrm{p}$ are checked (see Table 3).

Coefficients X9, X10 and X11 are statistically insignificant, as their $\mathrm{p}$ values (Sig.) are larger than 0.05 . Thus, they are removed from the equation, and the estimations are repeated after removing such values as crediting of the private sector, general tax level and minimum wages; the coefficient of determination remains unchanged at 0.99 . 
Table 1. Description of export determinants included in the correlation analysis (source: compiled by the authors with reference to the data of Lithuanian Department of Statistics, the World Bank, the LR State Tax Inspectorate)

\begin{tabular}{|c|c|}
\hline The independent variable & The independent variable description \\
\hline Business freedom index & $\begin{array}{l}\text { Business freedom is an overall indicator of the efficiency of business in a state. Quantitative index score } \\
\text { is calculated by assessing business start-up barriers, business development and obstacles of business } \\
\text { closing. Business freedom index value for each country varies from } 0 \text { to } 100 \text {, where } 100 \text { points represent } \\
\text { a completely free business environment. }\end{array}$ \\
\hline Corruption freedom index & $\begin{array}{l}\text { Corruption erodes economic freedom by introducing a sense of insecurity and uncertainty into econo- } \\
\text { mic relations. Corruption Freedom Index is obtained from the Transparency International's Corruption } \\
\text { Perceptions Index. The Index is measured within a 10-point scale, where } 10 \text { indicates very little corruption, } \\
\text { while } 0 \text { - a very corrupt government. }\end{array}$ \\
\hline $\begin{array}{l}\text { General state's revenue } \\
\text { from taxes and social } \\
\text { contributions (percentage } \\
\text { of GDP) }\end{array}$ & $\begin{array}{l}\text { It refers to revenue from taxes in a country's budget. In Lithuania, over } 90 \text { percent of the state and mu- } \\
\text { nicipal budget revenues are composed of tax revenues. The largest receipts to the national budget are } \\
\text { from value-added tax, personal income tax and excise duty. }\end{array}$ \\
\hline $\begin{array}{l}\text { Foreign direct investment, } \\
\text { net flows, in \$ }\end{array}$ & $\begin{array}{l}\text { Foreign direct investment refers to direct investment flows from abroad in the current economy. It } \\
\text { is the overall amount of invested private capital, re-investment of obtained returns and the general } \\
\text { amount of other capital. This category of investment from abroad is associated with the situation when } \\
\text { a country's resident controls or has a significant impact on the management of the company situated in } \\
\text { another country. The property of } 10 \text { or more percent of ordinary shares providing voting rights is the } \\
\text { main criterion for determining of whether there exists any possibility of direct investment relationships } \\
\text { between the operators. }\end{array}$ \\
\hline GDP per capita, EUR & $\begin{array}{l}\text { GDP per capita is gross domestic product divided by the number of population of a country in the middle } \\
\text { of a year. It is the general amount of the added-value developed by the population for the economy plus any } \\
\text { product/service taxes less subsidies, which are not included in the product/service value. GDP per capita } \\
\text { is calculated before considering the depreciation of assets or the factors of natural resource depletion. }\end{array}$ \\
\hline $\begin{array}{l}\text { General labour force, per- } \\
\text { centage }\end{array}$ & $\begin{array}{l}\text { This is a ratio of a number of people who are physically or mentally capable of doing work and are avai- } \\
\text { lable for work to a general number of the population of a country or region. Labour force includes both } \\
\text { the employed and the unemployed, provided that they want to work and actually seek a job. }\end{array}$ \\
\hline $\begin{array}{l}\text { Unemployment rate, per- } \\
\text { centage, of general labour } \\
\text { force }\end{array}$ & $\begin{array}{l}\text { The standard jobless economic characteristics is about the unemployed who have been recently looking } \\
\text { for work and are currently available for work. Individuals who have not been looking for work in the } \\
\text { recent period, but are in an agreement for the future work are also considered as unemployed. In other } \\
\text { words, the unemployed make a potential labour force or economically active population that is the basis } \\
\text { of the unemployment rate in a country or region. }\end{array}$ \\
\hline $\begin{array}{l}\text { Minimum wages, } \\
\text { EUR/month }\end{array}$ & $\begin{array}{l}\text { Minimum wages statistics, declared by Eurostat, is a national minimum amount of a monthly wage. In } \\
\text { some countries, the basic minimum wage rate is fixed at the monthly and hourly or weekly basis for work. } \\
\text { Therefore, the hourly or weekly wage rates for such countries are converted into monthly rates. Minimum } \\
\text { wages are set by law, often after consultation with the social partners, or directly in accordance with } \\
\text { national inter-sectoral agreement. The minimum wage is usually applied to all employees, or at least to } \\
\text { the majority in a country. This is a gross salary amount before income and social contribution deduction. }\end{array}$ \\
\hline $\begin{array}{l}\text { Inflation in consumer pri- } \\
\text { ces, percentage }\end{array}$ & $\begin{array}{l}\text { Inflation is measured by the consumer price index which reflects the annual percentage change in the } \\
\text { average cost to a consumer to obtain the cart goods or services at identified or modified intervals, for } \\
\text { example, every year. As usual, inflation rate is measured by employing Laspeyres formula. }\end{array}$ \\
\hline $\begin{array}{l}\text { Crediting of the private } \\
\text { sector, percentage, of GDP }\end{array}$ & $\begin{array}{l}\text { Crediting of the private sector means providing the supply of financial resource, such as loans, property } \\
\text { purchase securities, trade credits and other amounts to be repaid, for the private sector by financial corpo- } \\
\text { rations. In some countries, crediting includes the public sector as well. Financial corporations involve cash } \\
\text { controlling institutions and banks, as well as other financial corporations, the data of whose are available } \\
\text { (including corporations that do not accept deposits of circulation, but assume the following commitment, } \\
\text { as savings or fixed-time deposits). Other instances of financial corporations can be financial or leasing } \\
\text { companies, money lenders, insurance companies, pension funds and currency exchange companies. }\end{array}$ \\
\hline $\begin{array}{l}\text { General tax level, percen- } \\
\text { tage of commercial profits }\end{array}$ & $\begin{array}{l}\text { General tax rate is the amount that includes tax and compulsory contributions paid by businessmen } \\
\text { after deductions and tax facilities, as a part of commercial profits. Taxes deducted from other entity (e.g., } \\
\text { person's income tax withheld and paid per employee by his/her employer) or collected taxes, which are } \\
\text { then recovered from public authorities (e.g., VAT, sales tax, service charges, etc.), are not included into } \\
\text { the general tax level. }\end{array}$ \\
\hline
\end{tabular}


Table 2. The values of Pearson's correlation coefficient (source: compiled by the authors)

\begin{tabular}{|c|c|c|}
\hline No. & Factors & Pearson's correlation coefficient \\
\hline $\mathrm{X} 1$. & Business freedom index & -0.267 \\
\hline $\mathrm{X} 2$. & Unemployment rate, percentage of the overall labour force & 0.209 \\
\hline X3. & GDP per capita, EUR & $0.926(p=0.000)$ \\
\hline $\mathrm{X} 4$. & Foreign direct investment, net flows, in dollars & -0.363 \\
\hline $\mathrm{X} 5$. & Corruption freedom index & 0.483 \\
\hline X6. & General labour force, percentage & -0.524 \\
\hline X7. & General state's revenue from taxes and social contribution (GDP percentage) & $-0.804(p=0.009)$ \\
\hline $\mathrm{X} 8$. & Inflation in consumer prices, percentage & -0.586 \\
\hline X9. & Crediting of the private sector, percentage, based on GDP & $0.937(p=0.000)$ \\
\hline $\mathrm{X} 10$. & General tax level, as a percentage of commercial profits & $-0.782(p=0.013)$ \\
\hline X11. & Minimum wages, EUR/month & $0.779(p=0.013)$ \\
\hline
\end{tabular}

Table 3. Values (p) of the multiple regression model (source: compiled by the authors)

\begin{tabular}{|l|c|}
\hline \multicolumn{1}{|c|}{ Model } & Sig. \\
\hline X 3 GDP per capita, EUR & 0.019 \\
\hline X 7 General state's revenue from taxes and social contributions (percentage of GDP) & 0.004 \\
\hline X 9 Crediting of the private sector, percentage of GDP & 0.078 \\
\hline X 10 General tax level, percentage of commercial profits & 0.290 \\
\hline X 11 Minimum wages, EUR/month & 0.996 \\
\hline
\end{tabular}

It can be stated that all the values are statistically significant and different from 0 , thus, the following equation is developed:

$$
\begin{gathered}
\text { Export }=4 \times 10^{\wedge} 7+2228.074 \times \text { GDP, per capita }- \\
1533479 \times \text { General state's revenue from taxes } \\
\text { and social contribution. }
\end{gathered}
$$

The standardized coefficients ( 0.697 and -0.433 ) reveal that GDP has a greater impact on Lithuanian export than general state's revenue from taxes and social contribution.

The estimations of the correlation and regression models lead to the following empirical findings:

- The values of Pearson's correlation coefficient revealed the strongest correlation, in terms of linearity. A very strong positive correlation was found between Lithuanian export and GDP per capita, EUR. Thus, an improving economic situation has an impact on the rise in the volumes of Lithuanian export, and vice versa;

- A strong negative correlation was found between Lithuanian export and general state's revenue from taxes and social contributions. It can be assumed that an increase in the revenues, collected from taxpayers, has an impact on the volumes of the country's export (its decrease and increase). The rise in taxes has an adverse impact on businesses eager to export;
- A very strong positive correlation was found between Lithuanian export and crediting of the private sector, percentage of GDP. Thus, the country's export is expected to grow if better conditions for crediting of small and medium-sized businesses are provided. In many cases, businesses need external funding in order to develop their exports in foreign markets. Unfortunately, the situation in Lithuania is hardly conducive to export development. Commercial banks are reluctant to credit private businesses, so non-bank funding (e.g., issuance of corporate bonds, using peer-to-peer funding) is often the only choice.

- A moderate negative correlation was found between Lithuanian export and general tax level. When taxes are rising, a larger part of businesses become not capable of paying them, so exports to international markets decrease, and vice versa;

- A moderate positive correlation was found between Lithuanian export and minimum wages. This connection is associated with GDP growth when living standards are improving and export volumes are increasing.

- The multiple regression analysis revealed that 99.1 percent of the changes in the volume of Lithuanian export can be explained by GDP per capita and the general state's revenue from taxes and social 
contributions (percentage of GDP). Since crediting of the private sector, general tax level and minimum wages were found to be statistically insignificant, they were removed from the model.

The estimations revealed that such variables as GDP per capita and general state's revenue from taxes and social contributions are independent and thus not correlated (sig. asymp. $0.138 ; \mathrm{r}=-0.535$, i.e. there is no statistically significant relation between the variables $(\mathrm{p}=0.138>0.05)$; Durbin-Watson statistic of 2.076 is close to 2 - it falls into the interval $[1.5 ; 2.5]$, which, in its turn, proposes that there is no autocorrelation between the variables).

The hypothesis on the normality of the distribution of standardized residuals was confirmed ( $p=0.950>0.05)$, which leads to the conclusion that the model is applicable for forecasting (the necessary condition was satisfied). The mean absolute percentage error (MAPE) was equal to 2.26 percent, i.e. less than 10 percent, which proposes that the model reflects actual values with appropriate accuracy.

\section{Conclusions}

Summarising, the following conclusions can be made:

1. Export has a significant positive impact on the competitiveness of any country, and the magnitude of this impact depends on the efficiency of particular industries and their abilities to provide foreign markets with the products that are accepted not only in the domestic market. The degree of export competitiveness is conditioned by the following groups of determinants: socio-demographic (human resources and capital, demographic situation), economic (BVP, FDI, employment rate, consumer price index, inflation rate, currency exchange rate, market regulation), ecological and environmental (ecological requirements, environmental norms), cultural (business environment, marketing, social attitudes), technological (high-tech level of industry, intensity of technology, innovation) and competitive (mechanisms of a market balance). The competitiveness of a country also depends on its geographical position and specialisation of industrial sectors.

2. From the methodological point of view, export competitiveness is commonly measured by employing RCA and $\mathrm{HI}$ indices. Unlike the majority of scientific studies, this research employs multiple regression analysis and Pearson's correlation coefficient for assessment of the impact of macroeconomic determinants on the competitiveness of Lithuanian export.

3. The mathematical estimations have revealed that GDP per capita, and general state's revenue and social security contributions by 99.1 percent explain the changes in Lithuanian export over the period 2007-2015. Some other factors that also had an impact on the country's export over the period under consideration include:

- a very strong positive relationship between export and crediting of the private sector;

- a moderate negative relationship between export and the general tax level;

- a moderate positive relationship between export and minimum wages.

Hence, in order to form a promotive export and development strategy, the government of the country should consider the factors the impact of which has been found to significantly affect the volumes of the country's export over the period under research.

\section{Discussion}

The latest strategy of Lithuanian export development for 2014-2020 raises the aim to achieve an increase in the share of the export of goods and services up to 100 percent of GDP in 2020 (calculating from the level of 2013) (Ministry of Economy of the Republic of Lithuania (2015), “The Guidelines of Export Development for 2014-2020”). It should also be noted that the development of Lithuanian export is affected not only by the macroeconomic situation in the country, manifesting through GDP, but also by the macroeconomic situation in other countries and business competitiveness which is promoted through technologies and investment in machinery and equipment (the group of technological factors). Another important finding is that the size of the general state's revenue and social security contributions explains the changes in the country's export. It proposes that the country's government should pay more attention to the analysis of taxation and tax environment. The further research could address the issue of how the changes in tax environment affect the activities of export companies.

\section{References}

Àlvarez R, Faruq H, Ópez RAL (2013) Is previous export experience important for new exports? The Journal of Development Studies 49 (3): 426-441. https://doi.org/10.1080/00220388.20 12.720368

Bojnec Š, Fertö I (2017) The duration of global agri-food export competitiveness. British Food Journal 119 (6): 1378-1393. https://doi.org/10.1108/BFJ-07-2016-0302

Bruneckienė J, Paltanavičienė D (2012) Measurement of export competitiveness of the Baltic States by Composite Index. Inzinerine Ekonomika - Engineering Economics 23 (1): 50-62. https://doi.org/10.5755/j01.ee.23.1.1218

Burange LG, Karnik NN (2014) An analysis of the export competitiveness of BRIC. ISFIRE Working paper series 4, September.

Deng Z, Hou L (2014) Financial underdevelopment, distorted lending and export market survival. The Journal of International Trade \& Economic Development 23 (5): 600-625. https://doi.org/10.1080/09638199.2013.771696 
Durand M, Giorno C (1987) Indicators of international competitiveness: conceptual aspects and evaluation. OECD economic studies, 147-197.

Feestra RC (2003) Advanced international trade. Princeton University Press, Princeton.

Fetscherin M, Alon I, Johnson James P (2010) Assessing the export competitiveness of Chinese industries. Asian Business \& Management 9 (3): 401-424. https://doi.org/10.1057/ abm. 2010.13

Heckscher E (1919) The effect of foreign trade on the distribution of income. Ekonomisk Tidskrift, 497-512. Reprinted as Chapter 13 in AEA. (1949). Readings in the Theory of International Trade, 272-300 (Philadelphia: Blakiston) with a Translation in Flam H, Flanders MJ (Eds) (1991). Heckscher-Ohlin Trade Theory 43-69. Cambridge: MIT Press.

Huo H (2014) Impact of country-level factors on export competitiveness of agriculture industry from emerging markets. Competitiveness Review 24 (5): 393-413. https://doi.org/10.1108/ CR-01-2012-0002

Kalèdienè J, Miliauskas G (2011) Lithuanian export competitiveness before economic recession. $\mathrm{BEH}-$ Business and Economic Horizons (4): 40-51. https://doi.org/10.15208/ beh.2011.4

Kalendienė J (2014) Assessment of Lithuanian export competitiveness in EU market. Taikomoji ekonomika: sisteminiai tyrimai 8 (1): 67-77. https://doi.org/10.7220/ AESR.1822.7996.2014.8.1.4

Katsikeas CS, Piercy NF, Ioannidis Ch (1996) Determinants of export performance in a European context. European Journal of Marketing 30 (6): 6-35. https://doi.org/10.1108/ 03090569610121656

Langvinienė N, Sekliuckienė J, Vengrauskas PV (2010) Tarptautinis verslas [International business]. Kaunas. Leidykla „Technologija“, 215.

Lederman D, Olarreaga M, Zavala L (2016) Export promotion and firm entry into and survival in export markets. Canadian Journal of Development Studies 37 (2): 142-158. https://doi. org/10.1080/02255189.2016.1131671

LR State Tax Inspectorate (2016) Biudžeto pajamos [Budget income] https://www.vmi.lt/cms/biudzeto-pajamos

Masmoudi M, Charfi F (2013) The macro-economic determinants of export competitiveness of the Tunisian Economy in a context of liberalization and crisis. International Journal of Business and Management Invention 2 (7): 36-49.

Melnikas B (2014) Tarptautinis verslas [International business]. Vilnius: Technika, 464.

Ministry of Economy of the Republic of Lithuania (2015) The guidelines of export development for 2014-2020 https://ukmin.lrv.lt/en/sector-activities/export/export-promotion-policy

Misztal P (2009) International competitiveness of the Baltic States in the transformation period: Lithuania, Latvia, Estonia. Transformations in Business \& Economics 8, 3 (18): 21-35.
Morgan ER (1997) Export stimuli and export barriers: evidence from the empirical research studies. European Business Review 97 (2): 68-79. https://doi.org/10.1108/09555349710162571

Muratoğlu G, Muratoğlu Y (2016) Determinants of export competitiveness: evidence from OECD manufacturing. Journal of Economics and Political Economy 3 (1): 111-118.

Lietuvos eksporto plètros strategija 2014-2020 [The strategy of Lithuanian export development] https://ukmin.lrv.lt/uploads/ ukmin/documents/files/AR_2017-09-15\%20(1).pdf

Pascucci F (2018) The export competitiveness of Italian coffee roasting industry. British Food Journal 120 (7): 1529-1546. https://doi.org/10.1108/BFJ-05-2017-0306

Pridotkienè J (2011) Prekinio kredito rizikos veiksnių vertinimas: Rytų ir Vakarų rinkų rizikingumas eksportuotojo požiūriu [Commodity's credit risk assessment factors: the Eastern and Western market risk from the exporter's perspective]. Economics and management 16: 273-279.

Pucar S (2012) The influence of intellectual capital on export performance. Journal of Intellectual Capital 13: 248-261. https://doi.org/10.1108/14691931211225715

Ricardo D (1951) The works and correspondence of David Ricardo. In: Sfaffa P (Ed). Cambridge University Press, Cambridge.

Romero-Márquez I, Moreno-Brid JC (2015) Export competitiveness in an oil and gas economy: the case of Trinidad and Tobago, 1985-2010. Cepal Review 117: 41-63.

Saboniene A (2009) Lithuanian export competitiveness: comparison with other Baltic States. Inzinerine EkonomikaEngineering Economics (2): 49-57.

Sabonienè A (2011) The changes of Lithuanian export competitiveness in the context of economic crisis. Economics and management 16: 302-308.

Sabonienė A (2014) Quality mode of Lithuanian manufacturing industry's exports. Engineering Economics 25 (4): 450-457. https://doi.org/10.5755/j01.ee.25.4.6925

Tyson L (1992) Who's bashing whom? Trade conflict in hightechnology industries. Institute for International Economics, Washington, DC.

Umbrasienè G (2014) Analysis of cyclical sensitivity in traditional and new sectors: the case of Lithuanian economy. Engineering Economics 25: 420-426. https://doi.org/10.5755/j01. ee.25.4.2055

Vijeikis J (2012) Konkurencingumo valdymo lygmenys ir veiksniai globalizacijos sąlygomis. Ekonomikos ir verslo socialiniai aspektai [Competitiveness management levels and factors of globalization. Economic and social aspects of business] Ekonominès ir socialinès politikos studijos, 223-237.

World bank (2016) World development indicators http://databank.worldbank.org/data/reports.aspx? source=2\&series=FS. AST.PRVT.GD.ZS\&country=LTU 